\title{
Diet to Reduce the Metabolic Syndrome Associated with Menopause. The Logic for Olive Oil
}

\author{
Juan José Hidalgo-Mora ${ }^{1}$, Laura Cortés-Sierra ${ }^{1}$, Miguel-Ángel García-Pérez ${ }^{2}{ }^{\circledR}$, Juan J. Tarín ${ }^{3}$ \\ and Antonio Cano 1,4,*iD \\ 1 Service of Obstetrics and Gynecology, Hospital Clínico Universitario-INCLIVA, Av Blasco Ibáñez 17, \\ 46010 Valencia, Spain; hidalgomorajj@gmail.com (J.J.H.-M.); cortes_lausie@gva.es (L.C.-S.) \\ 2 Department of Genetics, Faculty of Biological Sciences, University of Valencia, Burjassot, and INCLIVA, \\ Av Blasco Ibáñez 17, 46010 Valencia, Spain; Miguel.Garcia@uv.es \\ 3 Department of Cellular Biology, Functional Biology and Physical Anthropology, Faculty of Biological \\ Sciences, University of Valencia, Burjassot, 46100 Valencia, Spain; Juan.J.Tarin@uv.es \\ 4 Department of Pediatrics, Obstetrics and Gynecology, University of Valencia, Av Blasco Ibáñez 15, \\ 46010 Valencia, Spain \\ * Correspondence: antonio.cano@uv.es; Tel.: +34-96-983087
}

Received: 14 September 2020; Accepted: 14 October 2020; Published: 18 October 2020

\begin{abstract}
The rates of metabolic syndrome are increasing in parallel with the increasing prevalence of obesity, primarily due to its concomitant insulin resistance. This is particularly concerning for women, as the years around menopause are accompanied by an increase in visceral obesity, a strong determinant of insulin resistance. A fall in estrogens and increase in the androgen/estrogen ratio is attributed a determining role in this process, which has been confirmed in other physiological models, such as polycystic ovary syndrome. A healthy lifestyle, with special emphasis on nutrition, has been recommended as a first-line strategy in consensuses and guidelines. A consistent body of evidence has accumulated suggesting that the Mediterranean diet, with olive oil as a vital component, has both health benefits and acceptable adherence. Herein, we provide an updated overview of current knowledge on the benefits of olive oil most relevant to menopause-associated metabolic syndrome, including an analysis of the components with the greatest health impact, their effect on basic mechanisms of disease, and the state of the art regarding their action on the main features of metabolic syndrome.
\end{abstract}

Keywords: olive oil; metabolic syndrome; obesity; women; menopause; healthy ageing

\section{Introduction}

The metabolic syndrome (MetS) consists of a cluster of risk factors that increase the risk of type 2 diabetes and cardiovascular disease (CVD) [1]. This cluster includes dysglycemia, increased blood pressure, lipid abnormalities as defined by hypertriglyceridemia and low high-density lipoprotein (HDL) cholesterol, and central obesity [2]. A conservative estimate is that around 100 million people may be affected worldwide, but the figure might be higher [3]. This makes the MetS a public health issue with a definitive impact on any healthy ageing strategy.

The prevalence of this syndrome is distributed heterogeneously worldwide, with geographic region, ethnicity, sex, age, socio-economic status, and education among the factors playing a role. It is believed that insulin resistance is the link underpinning the clustering of these risk factors [1]. Obesity, particularly central obesity, is also understood as a trigger because of its predisposing effect on insulin resistance [4]. 


\section{Literature Search}

We conducted a PubMed database search for publications between 1 January 2000 and 1 October 2020, pairing the term "olive oil" with "metabolic OR metabolic syndrome OR obesity OR central obesity OR weight OR waist OR blood pressure OR cholesterol OR triglycerides OR lipids OR insulin resistance OR diabetes OR menopause". Only papers written in English or Spanish were considered, yielding a total of 7885 titles. The initial search considered the title, or title and abstract when the title raised uncertainty about the content of the paper, reducing the list to 251 articles. Systematic reviews and meta-analyses were included in the selection. We manually searched the reference lists of selected review papers to retrieve other citations of potential interest. Studies based on special populations (adolescents, transplant patients, pregnant women, etc.) were excluded. After cross-cleaning the lists, a total of 120 papers were chosen. (Figure 1).

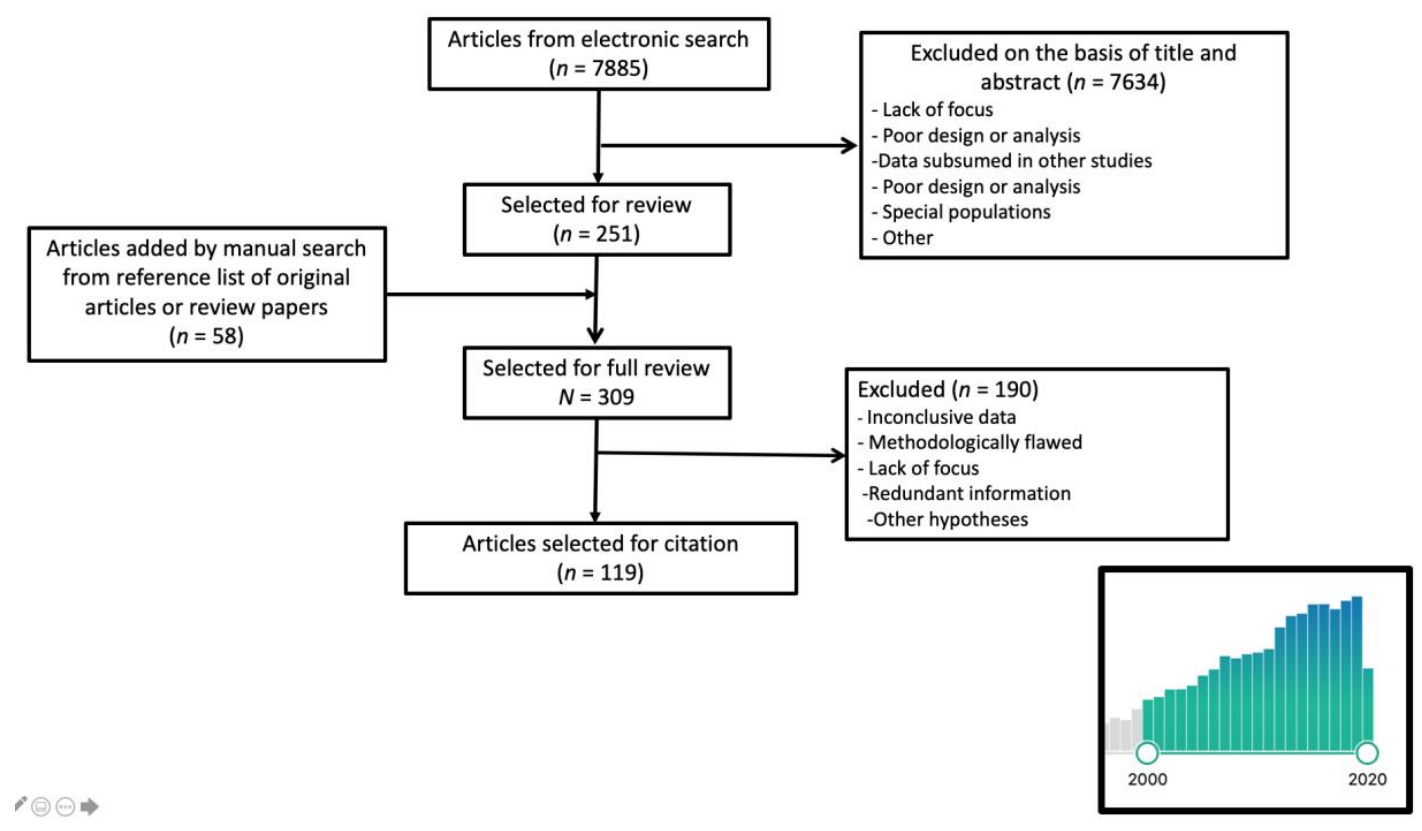

Figure 1. Literature search flowchart. The bars in the insert represent the trend in the numbers of papers published per year between 2000 and 2020. The year 2020 is incomplete because the search only included papers published until 1 October.

\section{Insulin Resistance in Menopausal Women}

The rates of all forms of obesity are rising rapidly worldwide, and the problem is expected to worsen [5]. The association between excessive calorie intake and inactive lifestyle from an early age onwards has led to a global epidemic affecting both poor and rich countries. Women are affected by this obesity epidemic equally as [5], if not more so than, men [6].

Central obesity is defined by the abdominal accumulation of fat, which can be located mainly at the subcutaneous or visceral level, or both. Central visceral rather than subcutaneous obesity is a major determinant of insulin resistance, which has been considered a driver of detrimental outcomes in the MetS [7]. As with men, central obesity also confers increased risk in women, as shown in the 10-year follow-up of 156,624 postmenopausal women enrolled in the Women's Health Initiative (WHI) cohort [8]. This finding is significant because unlike men, women have specific risk factors for central obesity. Indeed, women undergo dramatic hormonal changes at midlife, arising during the perimenopausal period, in which there is a significant decline in circulating estrogen levels [9]. Experimental and clinical studies concur that the fall in estrogens is associated with an increase in visceral fat [10-12]. Likewise, longitudinal population studies such as the Study of Women Across the Nation (SWAN) have confirmed that the odds of suffering from metabolic syndrome more than double 
in the years around the menopause [13]. This effect of menopause can undergo slight modifications according to ethnicity as a result of the different patterns of hormonal changes among women of different racial origins [14].

The potential contribution of hormonal changes other than those in estrogens has been studied in depth, with the case of polycystic ovary syndrome (PCOS) providing a good model [15]. Proof of the specific potential of hormones has been found in non-obese women presenting with PCOS, who also show an increased risk of MetS [16]. A relative increase in androgens vs. estrogens has been attributed a central role, although the issue is still a matter of some debate [17]. For example, androgen concentrations did not increase the risk for diabetes among overweight women who were already glucose intolerant in a secondary analysis of the Diabetes Prevention Program (DPP) and the Diabetes Prevention Program Outcomes Study (DPPOS) [18]. It might be that androgens distinct from testosterone, such as dehydroepiandrosterone-sulfate (DHEAS), could have a compensatory effect $[19,20]$.

The androgen/estrogen imbalance also occurs at the time of menopause because of the fall in estrogens in the presence of a much lower decline in androgens (Figure 2). Confirmatory evidence has been obtained in a group of postmenopausal women whose testosterone levels were measured with an ultrasensitive method and their body composition and abdominal deposits with dual energy X-ray absorptiometry (DXA) and magnetic resonance imaging, respectively [21].

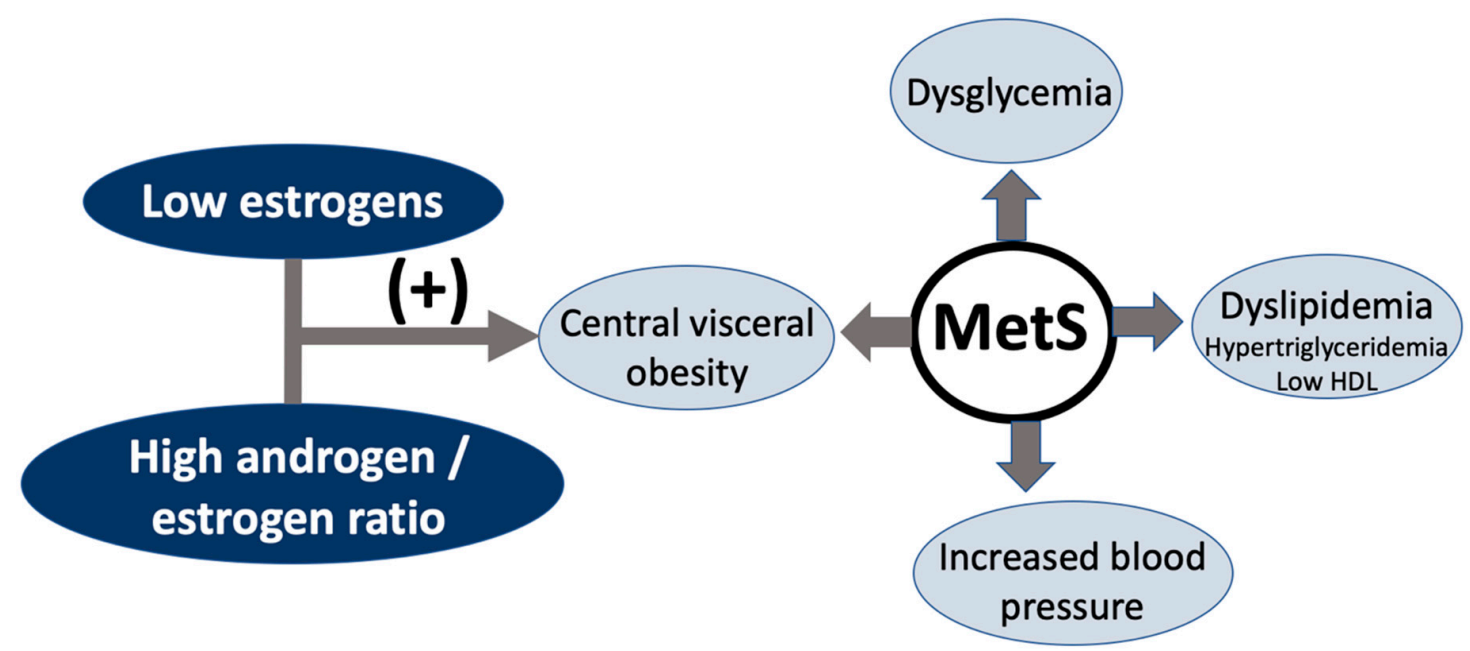

Figure 2. The metabolic syndrome (MetS) is defined as a cluster of four different risk factors, namely, dysglycemia, dyslipidemia, increased blood pressure, and central visceral obesity. While these affect both sexes, at midlife, women go through the menopause, which involves a rapid fall in estrogens and a very slow decline in androgens. Both the reduction in estrogens and the increase in the androgen/estrogen ratio have been attributed to promoting central obesity. Increased insulin resistance may then affect the other three factors in the cluster. HDL: high-density lipoprotein.

The potential influence of other factors cannot be excluded. For example, low levels of sex hormone binding globulin (SHBG) occurring when estrogen levels are low have been shown to be associated with the MetS and type 2 diabetes in both men and women [22,23]. More recent studies have gone further and have confirmed an increased risk for cardiovascular events. This was the conclusion from the observational cohort of 161,108 postmenopausal women enrolled in the Women's Health Initiative (WHI) study, in which an inverse association between the serum levels of SHBG and the incidence of ischemic stroke was found [24]. 
It seems that the hormonal regulation of fat distribution is a strong variable affecting the differing fat distribution patterns between sexes, but much of the detail is still unknown. The possibility that a healthy diet may limit these menopause-dependent changes is an attractive hypothesis. The PCOS model is again illustrative, as recent clinical studies have shown that diet can worsen, when unhealthy [25], or improve, when healthy [26], hormonal and metabolic changes in the PCOS phenotype.

\section{The Role of Healthy Nutrition}

Lifestyle has been recommended as a first-line measure against MetS. Physical activity [27] and healthy nutrition are the two most widely promoted interventions [28]. A notable recent initiative is the EAT-Lancet Commission, which has underlined the need to foment healthy diet patterns that are respectful to local traditions and the environment. A healthy reference diet has been defined, with a high consumption of fruits and vegetables together with a reduction of processed meat or refined sugar as the main features [29]. The Mediterranean diet (MedDiet) has been thoroughly investigated and received worldwide recognition as one of the healthiest options [30]. Interestingly, the MedDiet has recently been recommended as a useful ally to manage women's health needs during the menopause transition and after menopause [31].

Olive oil (OO) is among the most widely researched MedDiet components in both experimental models and clinical studies. Furthermore, indications in the literature suggest a role of OO in improving insulin sensitivity [32]. There is a dearth of studies specifically addressing the impact of OO on MetS disorders associated with menopause. However, there is considerable information on the action of $\mathrm{OO}$ on the mechanisms and the clinical features associated with the MetS. This information can be taken to better understand the effect of $\mathrm{OO}$ in limiting the development of MetS during menopause, as supported by a recent expert consensus [31]. In the coming sections, we will analyze the OO components with the greatest health impact, their effect on basic mechanisms of disease, and the state of the art regarding their action on the main components of MetS. Although there are four main OO subtypes (extra virgin, virgin, refined and pomace) [33], few studies discriminate by subtype, precluding us from considering them separately here.

\section{Components in Olive Oil with a Health Impact}

Olive oil includes a wealth of compounds, or compound families, in which unsaturated fat far exceeds saturated fats. Polyphenols form another group of compounds that contribute substantially to the health impact of $\mathrm{OO}$.

\subsection{Unsaturated Fat}

Olive oil conforms to the recommendation put forth since the Seven Countries study [34] that saturated fat should be replaced by unsaturated fat of vegetable origin. The main OO components are oleic acid $(70 \%)$, classed as a monounsaturated fatty acid (MUFA), and linoleic acid (15\%), a polyunsaturated fatty acid (PUFA). Other unsaponifiable fatty acids may also be present in OO, depending on whether the variant is refined, virgin or extra virgin [35] (Figure 3). 


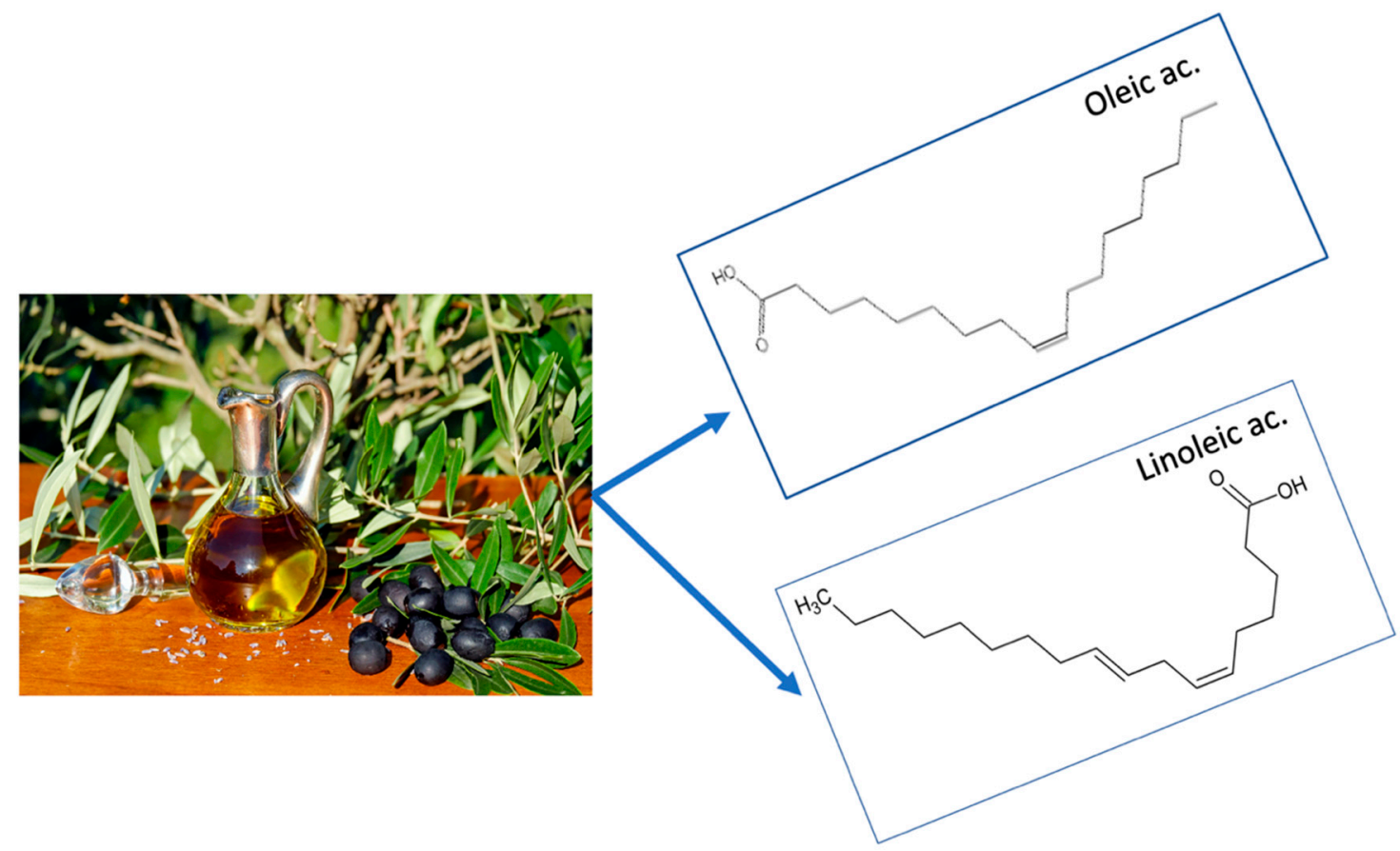

Figure 3. Olive oil is a source of unsaturated fat, whose two main components are oleic acid, a monounsaturated fat making up $70 \%$ of the total fat, and linoleic acid, a polyunsaturated fat representing $15 \%$ of the total fat content.

\subsection{Polyphenols}

Polyphenols are a family of phytochemicals with a molecular structure containing phenol rings. Present in a wide variety of food sources, the members of this large family include flavonoids, phenolic acids, lignans and stilbenes, all of which exhibit both antioxidant and anti-inflammatory properties [36,37].

One predominant characteristic of polyphenols is their metabolism in the intestine, where a huge number (ranging between 100,000 and 200,000) of secondary compounds are generated with the intervention of local microbiota. The concentration of secondary metabolites falls sharply, from the $\mathrm{mM}$ to $\mu \mathrm{M}$ range in the original source to the $\mathrm{nM}$ range in the plasma [38].

The metabolic impact is rapid, as shown in a crossover study in which a reduction in foods containing polyphenols was already reflected in a change in biomarkers, such as the ratio of thromboxane $\mathrm{A}_{2}$ and prostaglandin $\mathrm{I}_{2}$, in the urine at the first control at 2 weeks [39].

The interest in polyphenols stems from findings of studies in other foods, for example, in several types of fruits, cocoa, etc., in which those compounds conferred a health protective effect $[40,41]$. Studies with OO have also supported this benefit.

\section{Polyphenols in Olive Oil}

The benefits of the polyphenols in OO have been shown in studies assessing either the effect of the whole family or the specific roles played by particular components.

Total polyphenol excretion in the urine was analyzed in an ancillary sub-study of the PREvención con DIeta MEDiterránea (PREDIMED) trial aimed at testing the efficacy of a MedDiet supplemented with extra-virgin olive oil (EVOO) or nuts, versus a control diet consisting of a recommended low-fat diet for primary CVD prevention [42]. Those of the 1139 participating individuals in the highest tercile of total urinary polyphenol excretion exhibited a lower plasma concentration of inflammatory biomarkers and significant improvement in cardiovascular indicators, namely, blood pressure and lipidograms [36], as reviewed in [43]. A meta-analysis has confirmed that polyphenol content is associated with an improved profile of several cardiovascular risk factors [44]. 
The specific role of certain polyphenols in OO, such as hydroxytyrosol (HxT) [45] and oleocanthal [46], have attracted particular attention (Figure 4).

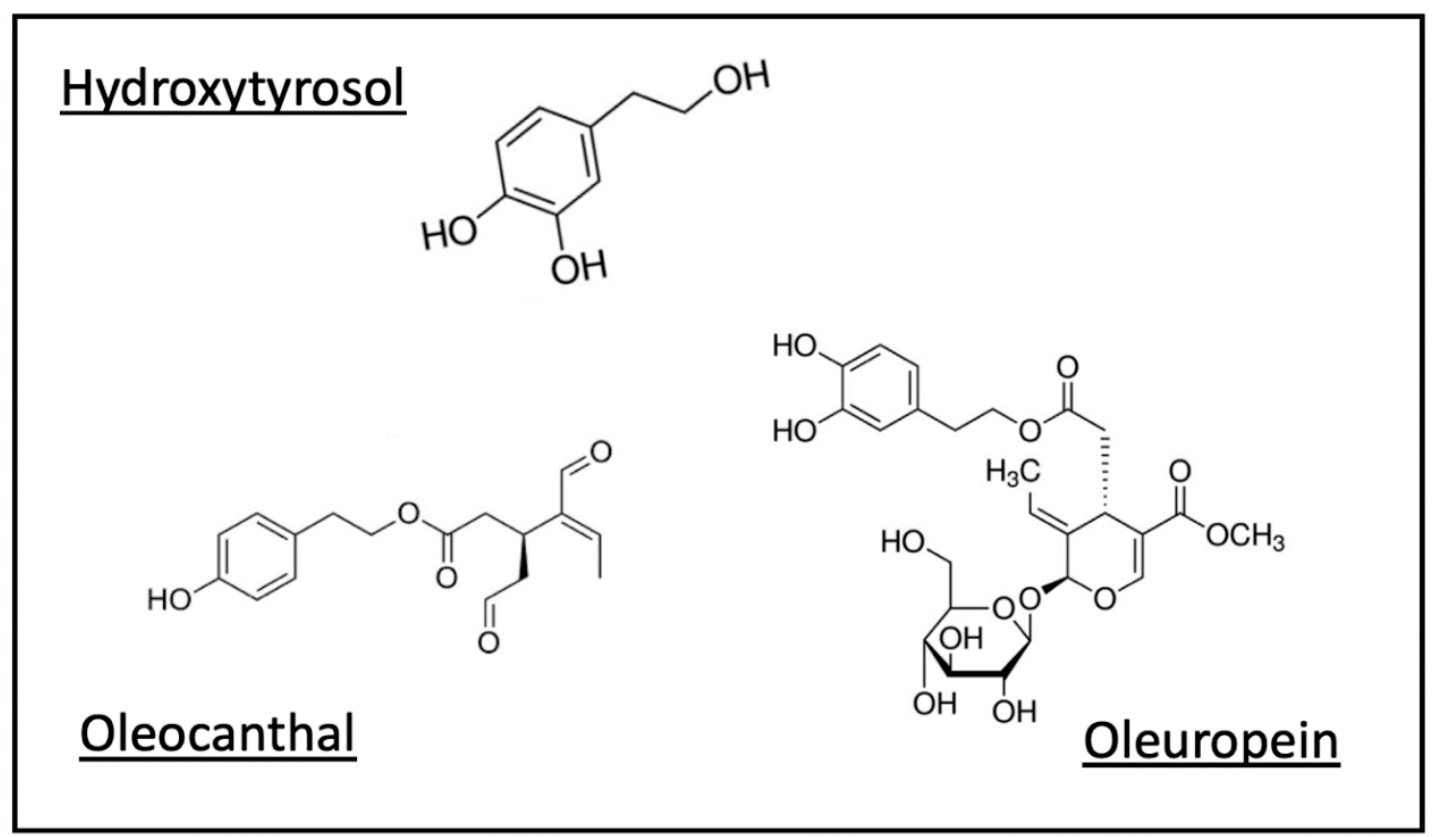

Figure 4. Polyphenols are a family of vegetal compounds characterized by phenol rings as part of their molecular structure. While the family includes a long list of compounds, current data can be found on the health benefits of some, with most available information centered on hydroxytyrosol, oleocanthal and oleuropein.

The levels of 3-O-methyl-hydroxytyrosol, a urinary metabolite of HxT, have been reported as inversely correlated with the risk of CVD and overall mortality in elderly subjects [47]. As shown in this study, one important feature of HxT concerns its good bioavailability, in contrast with resveratrol, another molecule that has been ascribed healthy properties based only upon benefits in experimental terms, since in vivo bioavailability is poor [48].

Oleuropein is an ester of HxT that in experimental models has shown preventive effects in early-stage cancer [49]. Work on breast, thyroid and colorectal cell lines has shown anti-proliferative potential and pro-apoptotic effects [49].

\section{Effect on General Mechanisms of Disease}

Homeostasis in the human body is a direct reflection of functional status at the cellular level. Cellular damage may be the result of various mechanisms, including defects in elementary cellular functions such as respiration or nutrition, and the noxious actions of external agents.

Inflammation and oxidative stress are two intertwined basic mechanisms that play key roles in cellular damage during processes such as ageing [50,51] and disease [52]. Nutrition, which provides micronutrients, metal ions, and other cofactors, is considered to regulate oxidative stress and inflammation [53,54]. Additionally, microbiota have been recognized as a mechanism strongly sensitive to diet.

\subsection{Inflammation and Oxidative Stress}

Inflammation is an important factor in the onset and progression of sub-clinical phases, as well as in the occurrence of clinical events, in several diseases including CVD [52,55], osteoporosis [56], cancer [57], neurodegenerative disorders and Alzheimer's disease, among others [58,59]. 
Oxidative stress, in turn, results from an imbalance between oxidant and antioxidant mechanisms. Reactive oxygen species (ROS) are small reactive molecules that regulate crucial biological processes. An excess of ROS generates reactions leading to DNA damage, the modification of proteins and the peroxidation of lipids. As has been noted for inflammation, these biological processes are involved in many diseases, such as atherosclerosis [60], type 2 diabetes [61] and others [62]. For example, a recognized effect of lipid peroxidation is an increase in oxidized LDL (oxLDL), a well-known pro-atherosclerotic factor [63]; this has led to proposed approaches to modulate oxidative stress (redox medicine) [53].

A close relationship exists between inflammation and oxidative stress [62]. For example, oxidative stress has been shown to intervene in the development and perpetuation of inflammation [64]. However, the opposite also occurs, as in the example of atherosclerosis, which is considered an oxidative response to inflammation [65].

\section{The Impact of Olive Oil}

The phenolic compounds in OO have shown a well-supported anti-inflammatory capacity [66-68], and clinical studies are confirmatory. The anti-inflammatory properties of the MedDiet have been demonstrated to be owing at least partly to OO [69]. Moreover, a study on high cardiovascular risk subjects showed that a higher intake of $\mathrm{OO}$ and nuts was associated with a reduction in several inflammatory markers, as exemplified by C-reactive protein, interleukin- 6 and certain adhesion molecules [70]. A more recent randomized controlled trial (RCT) confirmed a differential impact of OO triterpenes [71].

There is also abundant information on the antioxidant effects of $\mathrm{OO}$, which have been investigated using different experimental models [72]. The main MUFA in OO, oleic acid, is more resistant to oxidation than PUFAs. Phenolic compounds also show substantial antioxidant capacity [73-75], as is the case of HxT, which has demonstrated remarkable antioxidant potential in both in vitro and animal experiments—for a review, see $[67,76,77]$ —as well as in healthy volunteers [78]. The free radical scavenging potential of HxT has been recognized by the European Food Safety Authority [79]. The EUROLIVE study has provided additional clinical support in finding that the phenolic content in OO was directly related to a reduction in heart disease risk factors [80].

Considerable antioxidant and anti-inflammatory potential has also been exhibited by oleocanthal, a phenolic compound responsible for the burning sensation at the back of the throat when consuming EVOO [81,82], and by other phenolic compounds [83,84].

\subsection{Microbiota}

The development of metagenomics technology has advanced the genomic study of microbes in the body. There is growing evidence linking obesity and type 2 diabetes with dysbiosis, a term describing alteration in the composition of intestinal microbiota. Dysbiosis is associated with changes in the intestinal barrier, which facilitate metabolite access to crucial organs such as the liver or fat. An overload of molecules such as lipopolysaccharides (LPS) and other endotoxins results in inflammatory processes, leading to clinically relevant conditions such as the aforementioned obesity [85].

Diet has an important effect on microbiota profiles and turnover [86,87]; for example, it has been shown that the MedDiet may change the gut microbiota, which has a knock-on clinical impact [88]. With regard to OO, an association of the intake of this oil with an increase in the biodiversity of the intestinal microbiota has been shown in rodent models [69]. As a general conclusion, the fatty acids in OO favor composition patterns with a higher prevalence of species that hinder dysbiosis. Polyphenols, by contrast, act as prebiotics and favor, among others, the genus Bacteroidetes, which are attributed a protective role against atherosclerosis [89]. Other microbiota modifications have been linked with changes in MetS features or other beneficial outcomes [90-92].

Clinical studies are still sparse and limited by the difficulty of establishing a causative role for the observed microbiota changes in the investigated outcomes. One small-scale RCT researching the effect 
of an OO-enriched biscuit found an increase in the output of the gut microbiota and metabolic changes suggestive of reduced oxLDL, although no real change in oxLDL could be detected [93]. Another small-sized RCT found that taking polyphenol-enriched OO for 3 weeks decreased oxLDL levels while increasing bifidobacteria and phenolic metabolite populations [94].

\section{Impact on Metabolic Syndrome and Its Components}

The protective role of $\mathrm{OO}$ against disease was addressed in a meeting of the International Olive Council [95], which highlighted mechanistic studies related to the action of polyphenols and fatty acids. The effect of $\mathrm{OO}$ on the MetS has been directly addressed in studies assessing the impact either on the MetS itself, or separately on each MetS component.

\subsection{Metabolic Syndrome}

There are a wealth of experimental studies, principally with cell cultures or rodent models, showing a role for polyphenols, mainly HxT, in improving MetS features [96,97], including some key ones such as adiposity and insulin resistance [77].

Intervention clinical studies have also yielded some evidence in this area. Supplementing a diet with EVOO, at least 4 tablespoons per day as in the PREDIMED study, was followed by a reversion of the MetS (control vs. EVOO hazard ratio $(\mathrm{HR})=1.35$; $95 \%$ confidence intervals $(\mathrm{CI}): 1.15,1.58$ ) [98]. Some studies have used OO enriched with polyphenols, with mixed or inconclusive results [99] or with a reduction in certain features of the MetS, specifically, glycemia, blood pressure and LDL oxidation [100].

The current consensus is that more long-term RCTs are required to reach consistent conclusions [101]. Despite this, the international panel recommendation for MetS prevention and management through lifestyle included $\mathrm{OO}$ consumption at doses of 20-50 g/d along with the MedDiet [102].

\subsection{Lipids}

The EUROLIVE randomized trial found that the polyphenol content in OO was inversely associated with the total cholesterol/HDL ratio and triglyceride levels [80]. Other studies with virgin $\mathrm{OO}(30 \mathrm{~mL} / \mathrm{d})$ enriched with phenolic compounds and triterpenes have found increased HDL levels [103] and HDL functionality [104]. Further effects have been shown in smaller studies, including oxLDL reduction with polyphenol-enriched OO [94].

The differential impact of the polyphenols in $\mathrm{OO}$ has been analyzed in a meta-analysis including papers published up to December 2018. EVOO with a high phenolic content slightly reduced LDL cholesterol when compared with EVOO with low phenolic content (mean difference $-0.14 \mathrm{mmol} / \mathrm{L} ; 95 \%$ CI: $-0.28,-0.01$ ). Additional benefits were found for oxLDL, which showed an inverse dose-response relationship with the intake of phenolic compounds [105].

EVOO at the low dose of $10 \mathrm{~g}$ was also associated with a reduction in postprandial triglycerides in subjects with impaired fasting glucose levels [106]. Additionally related to this OO variant, PREDIMED has generated a list of sub-studies that have reported lipid changes associated with the EVOO-supplemented arm. Among these are a reduction in LDL atherogenicity, including resistance against oxidation, particle size, composition and cytotoxicity $[107,108]$ and an increased cholesterol efflux capacity of HDL [108].

\subsection{Blood Pressure}

Some studies have associated the MUFA in OO with a reduction in vascular tone [109], so a decrease in blood pressure may be expected. Polyphenols are also involved in vascular dilation, according to data obtained from experiments with rodents [110]. Some peptides in OO have also been confirmed to exhibit anti-hypertensive activity through an angiotensin-converting enzyme inhibitory activity [111]. 
Clinical studies are still sparse, as was acknowledged in a systematic review that, based on data from only 69 subjects, concluded that systolic, but not diastolic, blood pressure was reduced by $\mathrm{OO}$ [112]. This review did not include the PREDIMED sub-study, which found a small reduction (mean: $-2.3 \mathrm{~mm} \mathrm{Hg}$; 95\% CI: $-4.0,-0.5$ for systolic, and mean: $-1.2 \mathrm{~mm} \mathrm{Hg}$; 95\% CI: $-2.2,-0.2$ for diastolic) in the EVOO-supplemented arm after 1 year in a subset of 235 subjects, with a mean age of 66.5 years, at high cardiovascular risk (85.4\% with hypertension) [113]. It is unclear whether the effect may differ in individuals who are normotensive or free of other cardiovascular risk factors.

A more recent meta-analysis on the differential effects of distinct types of $O O$ found an inverse, dose-response association between the phenolic compounds from $\mathrm{OO}$ and systolic blood pressure in a secondary analysis [105].

\subsection{Body Weight and Waist Circumference}

There is experimental evidence supporting a protective effect of the HxT in OO against adiposity [77,97], as reviewed in [96], an action that has also been shown for other polyphenols such as europein [114].

Zamora et al. conducted a systematic review and meta-analysis of RCTs with at least 12 weeks' intervention in adults without CVD, analyzing papers published up to December 2016. Diets enriched in $\mathrm{OO}$ were more effective than control diets in weight reduction $(-0.92 \mathrm{~kg}$; $95 \% \mathrm{CI}:-1.16-0.67)$, waist circumference reduction $(-0.60 \mathrm{~cm} ; 95 \% \mathrm{CI}:-1.17,-0.04)$ and lowering body mass index (BMI) $\left(-0.90 \mathrm{~kg} / \mathrm{m}^{2} ; 95 \% \mathrm{CI}:-0.91,-0.88\right)$ [115]. PREDIMED was included in the analysis, and the authors acknowledged that the large scale of that study influenced the conclusion.

A subsequent RCT in which OO was compared with coconut oil and butter could not detect any change in weight or waist circumference, but both the sample size (91 subjects) and the intervention duration (4 weeks) were limited [116].

\subsection{Dysglycemia and Diabetes}

As for the previous MetS components, the data in this area derive from work focused on the impact of polyphenols on different experimental models. There is a general consensus in that $\mathrm{OO}$ components, and particularly polyphenols, improve glycemic control [117], as reviewed in [118].

Clinical studies have been included in a meta-analysis of prospective cohort studies and trials. The findings show that the risk of diabetes in individuals in the highest $\mathrm{OO}$ intake category was lower than in the lowest one (relative risk $(\mathrm{RR})=0.84 ; 95 \% \mathrm{CI}: 0.77,0.92$ ), and OO supplementation in subjects with type 2 diabetes was associated with a more pronounced reduction of $\mathrm{HbA} 1 \mathrm{c}$ and fasting glycemia than in control groups [119].

\section{Conclusions}

The incidence of MetS is growing rapidly in women. The trend is probably influenced by the increase in the rates of obesity as a result of the presence of comorbid insulin resistance. These difficulties are exacerbated in women around the time of the menopause, when hormonal changes begin to promote central obesity. Given the association of metabolic syndrome with disease, this is a vital issue in any strategy focused on healthy ageing.

Guidance is therefore needed to overcome the problem, particularly during the menopause, given that this occurs at midlife, a crucial moment during which the sub-clinical phases of many non-communicable diseases often emerge. A healthy lifestyle, with nutrition as a vital component, needs to be implemented as a primary measure. For successful adoption and adherence, a healthy diet needs to be easy to follow and effective, two conditions successfully met by the MedDiet. The results of the above-presented data indicate that $\mathrm{OO}$ is a key food in the MedDiet that may prove especially helpful for women, particularly during this life stage. Experimental and clinical studies in the literature have been used as support. The clinical evidence, however, is limited by the observational nature of most studies. 
Author Contributions: Conceptualization, J.J.H.-M., L.C.-S. and A.C.; methodology, J.J.H.-M., L.C.-S., M.-Á.G.-P. and J.J.T.; software, M.-Á.G.-P.; validation, M.-Á.G.-P., J.J.T. and A.C.; formal analysis, J.J.H.-M., L.C.-S., M.-Á.G.-P. and J.J.T.; resources, J.J.H.-M., L.C.-S., M.-Á.G.-P. and J.J.T.; data curation, M.-Á.G.-P. and J.J.T.; writing-original draft preparation, A.C.; writing-review and editing, A.C., J.J.H.-M. and L.C.-S.; visualization, J.J.H.-M., L.C.-S., M.-Á.G.-P., J.J.T. and A.C.; supervision, A.C.; project administration, A.C.; funding acquisition, M.-Á.G.-P., J.J.T. and A.C. All authors have read and agreed to the published version of the manuscript.

Funding: This research received funding from grant number 664367 FOCUS, from the Consumers, Health, Agriculture and Food Executive Agency (CHAFEA) of the European Commission, under the European Union Health Programme (2014-2020).

Conflicts of Interest: The authors declare no conflict of interest. The funders had no role in the design of the study; in the collection, analyses or interpretation of data; in the writing of the manuscript; or in the decision to publish the results.

\section{References}

1. Gluvic, Z.; Zaric, B.; Resanovic, I.; Obradovic, M.; Mitrovic, A.; Radak, D.; Isenovic, E. Link between Metabolic Syndrome and Insulin Resistance. Curr. Vasc. Pharmacol. 2017, 15, 30-39. [CrossRef]

2. Alberti, K.G.; Eckel, R.H.; Grundy, S.M.; Zimmet, P.Z.; Cleeman, J.I.; Donato, K.A.; Fruchart, J.-C.; James, W.T.P.; Loria, C.M.; Smith, S.C.; et al. International Diabetes Federation Task Force on Epidemiology and Prevention; Hational Heart, Lung, and Blood Institute; American Heart Association; World Heart Federation; International Atherosclerosis Society; International Association for the Study of Obesity. Harmonizing the metabolic syndrome: A joint interim statement of the International Diabetes Federation Task Force on Epidemiology and Prevention; National Heart, Lung, and Blood Institute; American Heart Association; World Heart Federation; International Atherosclerosis Society; and International Association for the Study of Obesity. Circulation 2009, 120, 1640-1645. [PubMed]

3. Roberts, C.K.; Hevener, A.L.; Barnard, R.J. Metabolic Syndrome and Insulin Resistance: Underlying Causes and Modification by Exercise Training. Compr. Physiol. 2013, 3, 1-58. [CrossRef]

4. Meyer, M.R.; Clegg, D.J.; Prossnitz, E.R.; Barton, M. Obesity, insulin resistance and diabetes: Sex differences and role of oestrogen receptors. Acta Physiol. 2011, 203, 259-269. [CrossRef] [PubMed]

5. OECD Obesity Update 2017. Available online: http://www.oecd.org/health/health-systems/Obesity-Update2017.pdf (accessed on 13 September 2020).

6. Ward, Z.J.; Bleich, S.N.; Cradock, A.L.; Barrett, J.L.; Giles, C.M.; Flax, C.; Long, M.W.; Gortmaker, S.L. Projected U.S. State-Level Prevalence of Adult Obesity and Severe Obesity. N. Engl. J. Med. 2019, 381, 2440-2450. [CrossRef] [PubMed]

7. Zhang, C.; Rexrode, K.M.; Van Dam, R.M.; Li, T.Y.; Hu, F.B. Abdominal obesity and the risk of all-cause, cardiovascular, and cancer mortality: Sixteen years of follow-up in US women. Circulation 2008, 117, 1658-1667. [CrossRef]

8. Sun, Y.; Liu, B.; Snetselaar, L.G.; Wallace, R.B.; Caan, B.J.; Rohan, T.E.; Neuhouser, M.L.; Shadyab, A.H.; Chlebowski, R.T.; Manson, J.E.; et al. Association of Normal-Weight Central Obesity With All-Cause and Cause-Specific Mortality Among Postmenopausal Women. JAMA Netw. Open 2019, 2, e197337. [CrossRef] [PubMed]

9. Davis, S.; Lambrinoudaki, I.; Lumsden, M.; Mishra, G.D.; Pal, L.; Rees, M.; Santoro, N.; Simoncini, T. Menopause. Nat. Rev. Dis. Prim. 2015, 1, 15004. [CrossRef]

10. Lovejoy, J.C.; Champagne, C.M.; De Jonge, L.; Xie, H.; Smith, S.R. Increased visceral fat and decreased energy expenditure during the menopausal transition. Int. J. Obes. 2008, 32, 949-958. [CrossRef]

11. Stubbins, R.E.; Holcomb, V.B.; Hong, J.; Núñez, N.P. Estrogen modulates abdominal adiposity and protects female mice from obesity and impaired glucose tolerance. Eur. J. Nutr. 2012, 51, 861-870. [CrossRef]

12. Shea, K.L.; Gavin, K.M.; Melanson, E.L.; Gibbons, E.; Stavros, A.; Wolfe, P.; Kittelson, J.M.; Vondracek, S.F.; Schwartz, R.S.; Wierman, M.E.; et al. Body composition and bone mineral density after ovarian hormone suppression with or without estradiol treatment. Menopause 2015, 22, 1045-1052. [CrossRef]

13. Janssen, I.; Powell, L.H.; Crawford, S.; Lasley, B.; Sutton-Tyrrell, K. Menopause and the Metabolic Syndrome: The Study of Women's Health Across the Nation. Arch. Intern. Med. 2008, 168, 1568-1575. [CrossRef] 
14. Marlatt, K.L.; Redman, L.M.; Beyl, R.A.; Smith, S.R.; Champagne, C.; Yi, F.; Lovejoy, J.C. Racial differences in body composition and cardiometabolic risk during the menopause transition: A prospective, observational cohort study. Am. J. Obstet. Gynecol. 2020, 222, 365.e1-365.e18. [CrossRef]

15. Otaghi, M.; Azami, M.; Khorshidi, A.; Borji, M.; Tardeh, Z. The association between metabolic syndrome and polycystic ovary syndrome: A systematic review and meta-analysis. Diabetes Metab. Syndr. Clin. Res. Rev. 2019, 13, 1481-1489. [CrossRef] [PubMed]

16. Zhu, S.; Zhang, B.; Jiang, X.; Li, Z.; Zhao, S.; Cui, L.; Chen, Z.-J. Metabolic disturbances in non-obese women with polycystic ovary syndrome: A systematic review and meta-analysis. Fertil. Steril. 2019, 111, 168-177. [CrossRef]

17. Dumesic, D.; Oberfield, S.E.; Stener-Victorin, E.; Marshall, J.C.; Laven, J.; Legro, R. Scientific Statement on the Diagnostic Criteria, Epidemiology, Pathophysiology, and Molecular Genetics of Polycystic Ovary Syndrome. Endocr. Rev. 2015, 36, 487-525. [CrossRef] [PubMed]

18. Kim, C.; Aroda, V.R.; Goldberg, R.B.; Younes, N.; Edelstein, S.L.; Carrion-Petersen, M.; Ehrmann, D.A.; Diabetes Prevention Program Outcomes Study Group. Androgens, Irregular Menses, and Risk of Diabetes and Coronary Artery Calcification in the Diabetes Prevention Program. J. Clin. Endocrinol. Metab. 2018, 103, 486-496. [CrossRef]

19. Paschou, S.A.; Anagnostis, P.; Goulis, D.G.; Siasos, G.; Vryonidou, A. Letter to the Editor: Androgens, Irregular Menses, and Risk of Diabetes and Coronary Artery Calcification in the Diabetes Prevention Program. J. Clin. Endocrinol. Metab. 2018, 103, 2066-2067. [CrossRef] [PubMed]

20. Brahimaj, A.; Muka, T.; Kavousi, M.; Laven, J.S.E.; Dehghan, A.; Franco, O.H. Serum dehydroepiandrosterone levels are associated with lower risk of type 2 diabetes: The Rotterdam Study. Diabetologia 2016, 60, 98-106. [CrossRef]

21. Ofori, E.K.; Alonso, S.C.; Correas-Gómez, L.; Carnero, E.A.; Zwygart, K.; Hugues, H.; Bardy, D.; Hans, D.; Dwyer, A.A.; Amati, F. Thigh and abdominal adipose tissue depot associations with testosterone levels in postmenopausal females. Clin. Endocrinol. 2019, 90, 433-439. [CrossRef] [PubMed]

22. Ding, E.L.; Song, Y.; Malik, V.S.; Liu, S. Sex differences of endogenous sex hormones and risk of type 2 diabetes: A systematic review and meta-analysis. JAMA 2006, 295, 1288-1299. [CrossRef]

23. Brand, J.S.; Van Der Tweel, I.; Grobbee, D.E.; Emmelot-Vonk, M.H.; Van Der Schouw, Y.T. Testosterone, sex hormone-binding globulin and the metabolic syndrome: A systematic review and meta-analysis of observational studies. Int. J. Epidemiol. 2011, 40, 189-207. [CrossRef] [PubMed]

24. Madsen, T.E.; Luo, X.; Huang, M.; Park, K.E.; Stefanick, M.L.; Manson, J.E.; Liu, S. Circulating SHBG (Sex Hormone-Binding Globulin) and Risk of Ischemic Stroke: Findings From the WHI. Stroke 2020, 51, 1257-1264. [CrossRef]

25. Kulkarni, S.D.; Patil, A.N.; Gudi, A.; Homburg, R.; Conway, G.S. Changes in diet composition with urbanization and its effect on the polycystic ovarian syndrome phenotype in a Western Indian population. Fertil. Steril. 2019, 112, 758-763. [CrossRef] [PubMed]

26. Barrea, L.; Arnone, A.; Annunziata, G.; Muscogiuri, G.; Laudisio, D.; Salzano, C.; Pugliese, G.; Colao, A.; Savastano, S. Adherence to the Mediterranean Diet, Dietary Patterns and Body Composition in Women with Polycystic Ovary Syndrome (PCOS). Nutrients 2019, 11, 2278. [CrossRef]

27. Myers, J.; Kokkinos, P.; Nyelin, E. Physical Activity, Cardiorespiratory Fitness, and the Metabolic Syndrome. Nutrients 2019, 11, 1652. [CrossRef] [PubMed]

28. Casu, L.; Gillespie, S.; Nisbett, N. Integrating nutrition and physical activity promotion: A scoping review. PLoS ONE 2020, 15, e0233908. [CrossRef]

29. Willett, W.; Rockström, J.; Loken, B.; Springmann, M.; Lang, T.; Vermeulen, S.; Garnett, T.; Tilman, D.; Declerck, F.; Wood, A.; et al. Food in the Anthropocene: The EAT-Lancet Commission on healthy diets from sustainable food systems. Lancet 2019, 393, 447-492. [CrossRef]

30. Sánchez-Sánchez, M.L.; García-Vigara, A.; Hidalgo-Mora, J.J.; García-Pérez, M.Á.; Tarín, J.; Cano, A. Mediterranean diet and health: A systematic review of epidemiological studies and intervention trials. Maturitas 2020, 136, 25-37. [CrossRef]

31. Cano, A.; Marshall, S.; Zolfaroli, I.; Bitzer, J.; Ceausu, I.; Chedraui, P.; Durmusoglu, F.; Erkkola, R.; Goulis, D.G.; Hirschberg, A.L.; et al. The Mediterranean diet and menopausal health: An EMAS position statement. Maturitas 2020, 139, 90-97. [CrossRef] 
32. De Bock, M.; Derraik, J.G.B.; Brennan, C.M.; Biggs, J.B.; Morgan, P.E.; Hodgkinson, S.C.; Hofman, P.L.; Cutfield, W.S. Olive (Olea europaea L.) leaf polyphenols improve insulin sensitivity in middle-aged overweight men: A randomized, placebo-controlled, crossover trial. PLoS ONE 2013, 8, e57622. [CrossRef] [PubMed]

33. Foscolou, A.; Critselis, E.; Panagiotakos, D.B. Olive oil consumption and human health: A narrative review. Maturitas 2018, 118, 60-66. [CrossRef]

34. Menotti, A.; Puddu, P.E. How the Seven Countries Study contributed to the definition and development of the Mediterranean diet concept: A 50-year journey. Nutr. Metab. Cardiovasc. Dis. 2015, 25, 245-252. [CrossRef] [PubMed]

35. Garcia-Aloy, M.; Hulshof, P.J.M.; Estruel-Amades, S.; Osté, M.C.J.; Lankinen, M.; Geleijnse, J.M.; De Goede, J.; Ulaszewska, M.; Mattivi, F.; Bakker, S.J.L.; et al. Biomarkers of food intake for nuts and vegetable oils: An extensive literature search. Genes Nutr. 2019, 14, 7. [CrossRef]

36. Medina-Remón, A.; Casas, R.; Tressserra-Rimbau, A.; Ros, E.; González, M.; Ángel, M.; Fitó, M.; Corella, D.; Salas-Salvadó, J.; Raventós, R.M.L.; et al. Polyphenol intake from a Mediterranean diet decreases inflammatory biomarkers related to atherosclerosis: A substudy of the PREDIMED trial. Br. J. Clin. Pharmacol. 2016, 83, 114-128. [CrossRef]

37. Oliviero, F.; Scanu, A.; Zamudio-Cuevas, Y.; Punzi, L.; Spinella, P. Anti-inflammatory effects of polyphenols in arthritis. J. Sci. Food Agric. 2017, 98, 1653-1659. [CrossRef]

38. Del Rio, D.; Rodriguez-Mateos, A.; Spencer, J.P.; Tognolini, M.; Borges, G.; Crozier, A. Dietary (Poly)phenolics in Human Health: Structures, Bioavailability, and Evidence of Protective Effects Against Chronic Diseases. Antioxidants Redox Signal. 2013, 18, 1818-1892. [CrossRef]

39. Hurtado-Barroso, S.; Quifer-Rada, P.; De Alvarenga, J.F.R.; Fernández, S.P.; Tresserra-Rimbau, A.; Lamuela-Raventós, R.M.; De Alvarenga, J.R. Changing to a Low-Polyphenol Diet Alters Vascular Biomarkers in Healthy Men after Only Two Weeks. Nutrients 2018, 10, 1766. [CrossRef]

40. Fernández-Murga, M.L.; Tarin, J.; García-Pérez, M.Á.; Cano, A. The impact of chocolate on cardiovascular health. Maturitas 2011, 69, 312-321. [CrossRef] [PubMed]

41. Cano-Marquina, A.; Tarín, J.J.; Cano, A. The impact of coffee on health. Maturitas 2013, 75, 7-21. [CrossRef]

42. Estruch, R.; Ros, E.; Salas-Salvadó, J.; Covas, M.-I.; Corella, D.; Aros, F.; Gómez-Gracia, E.; Ruiz-Gutiérrez, V.; Fiol, M.; Lapetra, J. PREDIMED Study Investigators. Primary Prevention of Cardiovascular Disease with a Mediterranean Diet Supplemented with Extra-Virgin Olive Oil or Nuts. N. Engl. J. Med. 2018, 378, e34. [CrossRef]

43. Castro-Barquero, S.; Tresserra-Rimbau, A.; Storelli, F.V.; Doménech, M.; Salas-Salvadó, J.; Martín, V.; Rubín-García, M.; Buil-Cosiales, P.; Corella, D.; Fitó, M.; et al. Dietary Polyphenol Intake is Associated with HDL-Cholesterol and A Better Profile of other Components of the Metabolic Syndrome: A PREDIMED-Plus Sub-Study. Nutrients 2020, 12, 689. [CrossRef] [PubMed]

44. George, E.S.; Marshall-Gradisnik, S.M.; Mayr, H.L.; Trakman, G.L.; Tatucu-Babet, O.A.; Lassemillante, A.-C.M.; Bramley, A.; Reddy, A.J.; Forsyth, A.; Tierney, A.C.; et al. The effect of high-polyphenol extra virgin olive oil on cardiovascular risk factors: A systematic review and meta-analysis. Crit. Rev. Food Sci. Nutr. 2019, 59, 2772-2795. [CrossRef]

45. de las Hazas, M.C.; Rubio, L.; Macià, A.; Motilva, M.J. Hydroxytyrosol: Emerging Trends in Potential Therapeutic Applications. Curr. Pharm. Des. 2018, 24, 2157-2179. [CrossRef] [PubMed]

46. Pang, K.-L.; Chin, K.-Y. The Biological Activities of Oleocanthal from a Molecular Perspective. Nutrients 2018, 10, 570. [CrossRef] [PubMed]

47. De La Torre, R.; Corella, D.; Castañer, O.; Martinez-Gonzalez, M.A.; Pintó, X.; Vila, J.; Estruch, R.; Sorlí, J.-V.; Arós, F.; Fiol, M.; et al. Protective effect of homovanillyl alcohol on cardiovascular disease and total mortality: Virgin olive oil, wine, and catechol-methylathion. Am. J. Clin. Nutr. 2017, 105, 1297-1304. [CrossRef] [PubMed]

48. Artero, A.; Artero, A.; Tarín, J.J.; Cano, A. The impact of moderate wine consumption on health. Maturitas 2015, 80, 3-13. [CrossRef]

49. Reboredo-Rodríguez, P.; Varela-López, A.; Forbes-Hernández, T.Y.; Gasparrini, M.; Afrin, S.; Cianciosi, D.; Zhang, J.; Manna, P.P.; Bompadre, S.; Quiles, J.L.; et al. Phenolic Compounds Isolated from Olive Oil as Nutraceutical Tools for the Prevention and Management of Cancer and Cardiovascular Diseases. Int. J. Mol. Sci. 2018, 19, 2305. [CrossRef] 
50. Kirkwood, T.B.L. Understanding the Odd Science of Aging. Cell 2005, 120, 437-447. [CrossRef]

51. López-Otín, C.; Blasco, M.A.; Partridge, L.; Serrano, M.; Kroemer, G. The Hallmarks of Aging. Cell 2013, 153, 1194-1217. [CrossRef]

52. Hansson, G.K. Inflammation, Atherosclerosis, and Coronary Artery Disease. New Engl. J. Med. 2005, 352, 1685-1695. [CrossRef]

53. Sies, H.; Berndt, C.; Jones, D.P. Oxidative Stress. Annu. Rev. Biochem. 2017, 86, 715-748. [CrossRef] [PubMed]

54. Elgebaly, H.A.; Mosa, N.M.; Allach, M.; El-Massry, K.F.; El-Ghorab, A.H.; Al Hroob, A.M.; Mahmoud, A.M. Olive oil and leaf extract prevent fluoxetine-induced hepatotoxicity by attenuating oxidative stress, inflammation and apoptosis. Biomed. Pharmacother. 2018, 98, 446-453. [CrossRef] [PubMed]

55. Ross, R. Atherosclerosis-An Inflammatory Disease. New Engl. J. Med. 1999, 340, 115-126. [CrossRef] [PubMed]

56. Kearns, A.E.; Khosla, S.; Kostenuik, P.J. Receptor activator of nuclear factor kappaB ligand and osteoprotegerin regulation of bone remodeling in health and disease. Endocr. Rev. 2008, 29, 155-192. [CrossRef] [PubMed]

57. Karki, R.; Man, S.M.; Kanneganti, T.-D. Inflammasomes and Cancer. Cancer Immunol. Res. 2017, 5, 94-99. [CrossRef]

58. Guo, H.; Callaway, J.B.; Ting, J.P.Y. Inflammasomes: Mechanism of action, role in disease, and therapeutics. Nat. Med. 2015, 21, 677-687. [CrossRef]

59. Katsumoto, A.; Takeuchi, H.; Takahashi, K.; Tanaka, F. Microglia in Alzheimer's Disease: Risk Factors and Inflammation. Front. Neurol. 2018, 9, 978. [CrossRef] [PubMed]

60. Kattoor, A.J.; Pothineni, N.V.K.; Palagiri, D.; Mehta, J.L. Oxidative Stress in Atherosclerosis. Curr. Atheroscler. Rep. 2017, 19, 42. [CrossRef]

61. Watson, J.D. Type 2 diabetes as a redox disease. Lancet 2014, 383, 841-843. [CrossRef]

62. Dandekar, A.; Mendez, R.; Zhang, K. Cross Talk Between ER Stress, Oxidative Stress, and Inflammation in Health and Disease. Recent Results Cancer Res. 2015, 1292, 205-214. [CrossRef]

63. Mitra, S.; Deshmukh, A.; Sachdeva, R.; Lu, J.; Mehta, J.L. Oxidized Low-Density Lipoprotein and Atherosclerosis Implications in Antioxidant Therapy. Am. J. Med Sci. 2011, 342, 135-142. [CrossRef] [PubMed]

64. Lugrin, J.; Rosenblatt-Velin, N.; Parapanov, R.; Liaudet, L. The role of oxidative stress during inflammatory processes. Biol. Chem. 2014, 395, 203-230. [CrossRef] [PubMed]

65. Stocker, R.; Keaney, J.F., Jr. Role of Oxidative Modifications in Atherosclerosis. Physiol. Rev. 2004, 84, 1381-1478. [CrossRef] [PubMed]

66. Casas, R.; Estruch, R.; Sacanella, E. The Protective Effects of Extra Virgin Olive Oil on Immune-mediated Inflammatory Responses. Endo. Metab. Immune Disord. Drug Targets 2017, 18, 23-35. [CrossRef]

67. De Pablos, R.M.; Espinosa-Oliva, A.M.; Hornedo-Ortega, R.; Cano, M.; Argüelles, S. Hydroxytyrosol protects from aging process via AMPK and autophagy; a review of its effects on cancer, metabolic syndrome, osteoporosis, immune-mediated and neurodegenerative diseases. Pharmacol. Res. 2019, 143, 58-72. [CrossRef]

68. Santangelo, C.; Vari, R.; Scazzocchio, B.; De Sanctis, P.; Giovannini, C.; D'Archivio, M.; Masella, R. Anti-inflammatory Activity of Extra Virgin Olive Oil Polyphenols: Which Role in the Prevention and Treatment of Immune-Mediated Inflammatory Diseases? Endo. Metab. Immune Disord. Drug Targets 2018, 18, 36-50. [CrossRef]

69. Marcelino, G.; Hiane, P.A.; Freitas, K.D.C.; Santana, L.F.; Pott, A.; Donadon, J.R.; Guimarães, R.D.C.A. Effects of Olive Oil and Its Minor Components on Cardiovascular Diseases, Inflammation, and Gut Microbiota. Nutrients 2019, 11, 1826. [CrossRef]

70. Salas-Salvadó, J.; Garcia-Arellano, A.; Estruch, R.; Marquez-Sandoval, F.; Corella, D.; Fiol, M.; Gómez-Gracia, E.; Viñoles, E.; Arós, F.; Herrera, C.; et al. Components of the mediterranean-type food pattern and serum inflammatory markers among patients at high risk for cardiovascular disease. Eur. J. Clin. Nutr. 2008, 62, 651-659. [CrossRef]

71. Sanchez-Rodriguez, E.; Biel, S.; Fernandez-Navarro, J.R.; Calleja-Hernández, M. Ÿngel; Espejo-Calvo, J.A.; Gil-Extremera, B.; De La Torre, R.; Fitó, M.; Covas, M.-I.; Vilchez, P.; et al. Effects of Virgin Olive Oils Differing in Their Bioactive Compound Contents on Biomarkers of Oxidative Stress and Inflammation in Healthy Adults: A Randomized Double-Blind Controlled Trial. Nutrients 2019, 11, 561. [CrossRef] 
72. Carnevale, R.; Nocella, C.; Cammisotto, V.; Bartimoccia, S.; Monticolo, R.; D'Amico, A.; Stefanini, L.; Pagano, F.; Pastori, D.; Cangemi, R.; et al. Antioxidant activity from extra virgin olive oil via inhibition of hydrogen peroxide-mediated NADPH-oxidase 2 activation. Nutrients 2018, 55-56, 36-40. [CrossRef] [PubMed]

73. Bogani, P.; Galli, C.; Villa, M.; Visioli, F. Postprandial anti-inflammatory and antioxidant effects of extra virgin olive oil. Atherosclerosis 2007, 190, 181-186. [CrossRef] [PubMed]

74. Carnevale, R.; Pignatelli, P.; Nocella, C.; Loffredo, L.; Pastori, D.; Vicario, T.; Petruccioli, A.; Bartimoccia, S.; Violi, F. Extra virgin olive oil blunt post-prandial oxidative stress via NOX2 down-regulation. Atherosclerosis 2014, 235, 649-658. [CrossRef] [PubMed]

75. Billingsley, H.E.; Carbone, S.; Lavie, C.J. Dietary Fats and Chronic Noncommunicable Diseases. Nutrients 2018, 10, 1385. [CrossRef]

76. Bernardini, E.; Visioli, F. High quality, good health: The case for olive oil. Eur. J. Lipid Sci. Technol. 2017, 119, 1500505. [CrossRef]

77. Wang, N.; Ma, Y.; Liu, Z.; Liu, L.; Yang, K.; Wei, Y.; Liu, Y.; Chen, X.; Sun, X.; Wen, D. Hydroxytyrosol prevents PM2.5-induced adiposity and insulin resistance by restraining oxidative stress related NF- $\mathrm{kB}$ pathway and modulation of gut microbiota in a murine model. Free. Radic. Biol. Med. 2019, 141, 393-407. [CrossRef]

78. Colica, C.; Di Renzo, L.; Trombetta, D.; Smeriglio, A.; Bernardini, S.; Cioccoloni, G.; De Miranda, R.C.; Gualtieri, P.; Salimei, P.S.; De Lorenzo, A. Antioxidant Effects of a Hydroxytyrosol-Based Pharmaceutical Formulation on Body Composition, Metabolic State, and Gene Expression: A Randomized Double-Blinded, Placebo-Controlled Crossover Trial. Oxid. Med. Cell. Longev. 2017, 2017, 2473495. [CrossRef]

79. European Food Safety Authority (efsa). Available online: https://www.efsa.europa.eu/en/efsajournal/pub/ 2033 (accessed on 12 September 2020).

80. Covas, M.-I.; Nyyssönen, K.; Poulsen, H.E.; Kaikkonen, J.; Zunft, H.-J.F.; Kiesewetter, H.; Gaddi, A.; De La Torre, R.; Mursu, J.; Bäumler, H.; et al. The effect of polyphenols in olive oil on heart disease risk factors: A randomized trial. Ann. Intern. Med. 2006, 145, 333-341. [CrossRef]

81. Smith, I.A.B.; Han, Q.; Breslin, A.P.A.S.; Beauchamp, G.K. Synthesis and Assignment of Absolute Configuration of (-)-Oleocanthal: A Potent, Naturally Occurring Non-steroidal Anti-inflammatory and Anti-oxidant Agent Derived from Extra Virgin Olive Oils. Org. Lett. 2005, 7, 5075-5078. [CrossRef]

82. Carpi, S.; Scoditti, E.; Massaro, M.; Polini, B.; Manera, C.; Digiacomo, M.; Salsano, J.E.; Poli, G.; Tuccinardi, T.; Doccini, S.; et al. The Extra-Virgin Olive Oil Polyphenols Oleocanthal and Oleacein Counteract Inflammation-Related Gene and miRNA Expression in Adipocytes by Attenuating NF- $\mathrm{BB}$ Activation. Nutrients 2019, 11, 2855. [CrossRef]

83. Cicerale, S.; Lucas, L.J.; Keast, R.S.J. Antimicrobial, antioxidant and anti-inflammatory phenolic activities in extra virgin olive oil. Curr. Opin. Biotechnol. 2012, 23, 129-135. [CrossRef] [PubMed]

84. Presti, G.; Guarrasi, V.; Gulotta, E.; Provenzano, F.; Giuliano, S.; Monfreda, M.; Mangione, M.; Passantino, R.; Biagio, P.S.; Costa, M.A.; et al. Bioactive compounds from extra virgin olive oils: Correlation between phenolic content and oxidative stress cell protection. Biophys. Chem. 2017, 230, 109-116. [CrossRef]

85. Tilg, H.; Zmora, N.; Adolph, T.E.; Elinav, E. The intestinal microbiota fuelling metabolic inflammation. Nat. Rev. Immunol. 2020, 20, 40-54. [CrossRef] [PubMed]

86. Gentile, C.L.; Weir, T.L. The gut microbiota at the intersection of diet and human health. Science 2018, 362, 776-780. [CrossRef] [PubMed]

87. Tindall, A.M.; Petersen, K.S.; Kris-Etherton, P.M. Dietary Patterns Affect the Gut Microbiome-The Link to Risk of Cardiometabolic Diseases. J. Nutr. 2018, 148, 1402-1407. [CrossRef]

88. Haro, C.; Montes-Borrego, M.; Rangel-Zuñiga, O.A.; Díaz, J.F.A.; Gomez-Delgado, F.; Perez-Martinez, P.; Gomez-Delgado, F.; Quintana-Navarro, G.M.; Tinahones, F.J.; Landa, B.B.; et al. Two Healthy Diets Modulate Gut Microbial Community Improving Insulin Sensitivity in a Human Obese Population. J. Clin. Endocrinol. Metab. 2016, 101, 233-242. [CrossRef]

89. Farràs, M.; Martinez-Gili, L.; Portune, K.; Arranz, S.; Frost, G.S.; Tondo, M.; Blanco-Vaca, F. Modulation of the Gut Microbiota by Olive Oil Phenolic Compounds: Implications for Lipid Metabolism, Immune System, and Obesity. Nutrients 2020, 12, 2200. [CrossRef] 
90. Prieto, I.; Hidalgo, M.; Segarra, A.B.; Martínez-Rodríguez, A.M.; Cobo, A.; Ramírez, M.; Abriouel, H.; Gálvez, A.; Martínez-Cañamero, M. Influence of a diet enriched with virgin olive oil or butter on mouse gut microbiota and its correlation to physiological and biochemical parameters related to metabolic syndrome. PLoS ONE 2018, 13, e0190368. [CrossRef]

91. Hidalgo, M.; Prieto, I.; Abriouel, H.; Villarejo, A.B.; Ramírez-Sánchez, M.; Cobo, A.; Benomar, N.; Gálvez, A.; Martínez-Cañamero, M. Changes in Gut Microbiota Linked to a Reduction in Systolic Blood Pressure in Spontaneously Hypertensive Rats Fed an Extra Virgin Olive Oil-Enriched Diet. Plant Foods Hum. Nutr. 2017, 73, 1-6. [CrossRef]

92. Martínez, N.; Prieto, I.; Hidalgo, M.; Segarra, A.B.; Martínez-Rodríguez, A.M.; Cobo, A.; Ramírez-Sánchez, M.; Gálvez, A.; Martínez-Cañamero, M. Refined versus Extra Virgin Olive Oil High-Fat Diet Impact on Intestinal Microbiota of Mice and Its Relation to Different Physiological Variables. Microorganisms 2019, 7, 61. [CrossRef]

93. Conterno, L.; Martinelli, F.; Tamburini, M.; Fava, F.; Mancini, A.; Sordo, M.; Pindo, M.; Martens, S.; Masuero, D.; Vrhovsek, U.; et al. Measuring the impact of olive pomace enriched biscuits on the gut microbiota and its metabolic activity in mildly hypercholesterolaemic subjects. Eur. J. Nutr. 2017, 58, 63-81. [CrossRef]

94. Martín-Peláez, S.; Mosele, J.I.; Pizarro, N.; Farràs, M.; De La Torre, R.; Subirana, I.; Pérez-Cano, F.J.; Castañer, O.; Solà, R.; Fernandez-Castillejo, S.; et al. Effect of virgin olive oil and thyme phenolic compounds on blood lipid profile: Implications of human gut microbiota. Eur. J. Nutr. 2017, 56, 119-131. [CrossRef] [PubMed]

95. Visioli, F.; Franco, M.; Toledo, E.; Luchsinger, J.; Willett, W.; Hu, F.; Martínez-González, M.A. Olive oil and prevention of chronic diseases: Summary of an International conference. Nutr. Metab. Cardiovasc. Dis. 2018, 28, 649-656. [CrossRef] [PubMed]

96. Peyrol, J.; Riva, C.; Amiot, M.J. Hydroxytyrosol in the Prevention of the Metabolic Syndrome and Related Disorders. Nutrients 2017, 9, 306. [CrossRef] [PubMed]

97. Poudyal, H.; Lemonakis, N.; Efentakis, P.; Gikas, E.; Halabalaki, M.; Andreadou, I.; Skaltsounis, A.-L.; Brown, L. Hydroxytyrosol ameliorates metabolic, cardiovascular and liver changes in a rat model of diet-induced metabolic syndrome: Pharmacological and metabolism-based investigation. Pharmacol. Res. 2017, 117, 32-45. [CrossRef] [PubMed]

98. Babio, N.; Toledo, E.; Estruch, R.; Ros, E.; Martínez-González, M.A.; Castañer, O.; Bulló, M.; Corella, D.; Arós, F.; Gómez-Gracia, E.; et al. Mediterranean diets and metabolic syndrome status in the PREDIMED randomized trial. Can. Med Assoc. J. 2014, 186, E649-E657. [CrossRef]

99. Amiot, M.J.; Riva, C.; Vinet, A. Effects of dietary polyphenols on metabolic syndrome features in humans: A systematic review. Obes. Rev. 2016, 17, 573-586. [CrossRef] [PubMed]

100. Saibandith, B.; Spencer, J.P.E.; Rowland, I.; Commane, D.M. Olive Polyphenols and the Metabolic Syndrome. Molecules 2017, 22, 1082. [CrossRef]

101. Chiva-Blanch, G.; Badimon, L. Effects of Polyphenol Intake on Metabolic Syndrome: Current Evidences from Human Trials. Oxid. Med. Cell. Longev. 2017, 2017, 1-18. [CrossRef]

102. Pérez-Martínez, P.; Mikhailidis, D.P.; Athyros, V.G.; Bullo, M.; Couture, P.; Covas, M.I.; De Koning, L.; Delgado-Lista, J.; Díaz-López, A.; Drevon, C.A.; et al. Lifestyle recommendations for the prevention and management of metabolic syndrome: An international panel recommendation. Nutr. Rev. 2017, 75, 307-326. [CrossRef]

103. Sanchez-Rodriguez, E.; Lima-Cabello, E.; Biel-Glesson, S.; Fernandez-Navarro, J.R.; Calleja-Hernández, M. Ÿngel; Roca, M.; Espejo-Calvo, J.A.; Gil-Extremera, B.; Soria-Florido, M.; De La Torre, R.; et al. Effects of Virgin Olive Oils Differing in Their Bioactive Compound Contents on Metabolic Syndrome and Endothelial Functional Risk Biomarkers in Healthy Adults: A Randomized Double-Blind Controlled Trial. Nutrients 2018, 10, 626. [CrossRef]

104. Pedret, A.; Fernández-Castillejo, S.; Valls, R.M.; Catalan, U.; Rubio, L.; Romeu, M.; Macia, A.; Lopez de las Hazas, M.C.; Farras, M.; Giralt, M. Cardiovascular Benefits of Phenol-Enriched Virgin Olive Oils: New Insights from the Virgin Olive Oil and HDL Functionality (VOHF) Study. Mol. Nutr. Food Res. 2018, 62, e1800456. [CrossRef] [PubMed]

105. Schwingshackl, L.; Krause, M.; Schmucker, C.; Hoffmann, G.; Rücker, G.; Meerpohl, J.J. Impact of different types of olive oil on cardiovascular risk factors: A systematic review and network meta-analysis. Nutr. Metab. Cardiovasc. Dis. 2019, 29, 1030-1039. [CrossRef] [PubMed] 
106. Carnevale, R.; Loffredo, L.; Del Ben, M.; Angelico, F.; Nocella, C.; Petruccioli, A.; Bartimoccia, S.; Monticolo, R.; Cava, E.; Violi, F. Extra virgin olive oil improves post-prandial glycemic and lipid profile in patients with impaired fasting glucose. Clin. Nutr. 2017, 36, 782-787. [CrossRef] [PubMed]

107. Damasceno, N.R.; Sala-Vila, A.; Cofán, M.; Pérez-Heras, A.M.; Fitó, M.; Ruiz-Gutiérrez, V.; Martínez-González, M.-A.; Corella, D.; Arós, F.; Estruch, R.; et al. Mediterranean diet supplemented with nuts reduces waist circumference and shifts lipoprotein subfractions to a less atherogenic pattern in subjects at high cardiovascular risk. Atherosclerosis 2013, 230, 347-353. [CrossRef] [PubMed]

108. Hernáez, Á.; Castañer, O.; Elosua, R.; Pintó, X.; Estruch, R.; Salas-Salvadó, J.; Corella, D.; Arós, F.; Serra-Majem, L.; Fiol, M.; et al. Mediterranean Diet Improves High-Density Lipoprotein Function in High-Cardiovascular-Risk Individuals: A Randomized Controlled Trial. Circulation 2017, 135, 633-643. [CrossRef] [PubMed]

109. Fuentes, F.; López-Miranda, J.; Pérez-Martínez, P.; Jiménez, Y.; Marín, C.; Gómez, P.; Fernández, J.M.; Caballero, J.; Delgado-Lista, J.; Pérez-Jiménez, F. Chronic effects of a high-fat diet enriched with virgin olive oil and a low-fat diet enriched with $\alpha$-linolenic acid on postprandial endothelial function in healthy men. Br. J. Nutr. 2008, 100, 159-165. [CrossRef] [PubMed]

110. Villarejo, A.; Ramírez-Sánchez, M.; Segarra, A.; Martínez-Cañamero, M.; Prieto, I. Influence of Extra Virgin Olive Oil on Blood Pressure and Kidney Angiotensinase Activities in Spontaneously Hypertensive Rats. Planta Med. 2014, 81, 664-669. [CrossRef]

111. Alcaide-Hidalgo, J.M.; Margalef, M.; Bravo, F.I.; Muguerza, B.; Lopez-Huertas, E.; Alcaide-Hidalgo, J.M. Virgin olive oil (unfiltered) extract contains peptides and possesses ACE inhibitory and antihypertensive activity. Clin. Nutr. 2020, 39, 1242-1249. [CrossRef]

112. Hohmann, C.D.; Cramer, H.; Michalsen, A.; Kessler, C.; Steckhan, N.; Choi, K.; Dobos, G. Effects of high phenolic olive oil on cardiovascular risk factors: A systematic review and meta-analysis. Phytomedicine 2015, 22, 631-640. [CrossRef]

113. Doménech, M.; Roman, P.; Lapetra, J.; De La Corte, F.J.G.; Sala-Vila, A.; De La Torre, R.; Corella, D.; Salas-Salvadó, J.; Ruiz-Gutiérrez, V.; Lamuela-Raventós, R.-M.; et al. Mediterranean diet reduces 24-h ambulatory blood pressure, blood glucose, and lipids: One-year randomized, clinical trial. Hypertension 2014, 64, 69-76. [CrossRef] [PubMed]

114. Kuem, N.; Song, S.J.; Yu, R.; Yun, J.W.; Park, T. Oleuropein attenuates visceral adiposity in high-fat diet-induced obese mice through the modulation of WNT10b- and galanin-mediated signalings. Mol. Nutr. Food Res. 2014, 58, 2166-2176. [CrossRef] [PubMed]

115. Zamora, F.Z.; Galiano, J.M.M.; Martínez, J.J.G.; Rodríguez, M.D. Olive Oil and Body Weight. Systematic Review and Meta-Analysis of Randomized Controlled Trials. Rev. Esp. Salud Publica 2018, 92, 201811083.

116. Khaw, K.-T.; Sharp, S.J.; Finikarides, L.; Afzal, I.; Lentjes, M.; Luben, R.; Forouhi, N.G. Randomised trial of coconut oil, olive oil or butter on blood lipids and other cardiovascular risk factors in healthy men and women. BMJ Open 2018, 8, e020167. [CrossRef]

117. Sangi, S.M.A.; Sulaiman, M.I.; El-Wahab, M.F.A.; Ahmedani, E.I.; Ali, S.S. Antihyperglycemic effect of thymoquinone and oleuropein, on streptozotocin-induced diabetes mellitus in experimental animals. Pharmacogn. Mag. 2015, 11 (Suppl. 2), S251-S257. [CrossRef] [PubMed]

118. Rigacci, S.; Stefani, M. Nutraceutical Properties of Olive Oil Polyphenols. An Itinerary from Cultured Cells through Animal Models to Humans. Int. J. Mol. Sci. 2016, 17, 843. [CrossRef]

119. Schwingshackl, L.; Lampousi, A.-M.; Portillo, M.P.; Romaguera, D.; Hoffmann, G.; Boeing, H. Olive oil in the prevention and management of type 2 diabetes mellitus: A systematic review and meta-analysis of cohort studies and intervention trials. Nutr. Diabetes 2017, 7, e262. [CrossRef]

Publisher's Note: MDPI stays neutral with regard to jurisdictional claims in published maps and institutional affiliations.

(C) 2020 by the authors. Licensee MDPI, Basel, Switzerland. This article is an open access article distributed under the terms and conditions of the Creative Commons Attribution (CC BY) license (http://creativecommons.org/licenses/by/4.0/). 